\title{
Rural-urban transformation: a key challenge of the 21st century
}

\author{
Andreas Buerkert $\mathbb{1} \cdot$ Eva Schlecht $\mathbb{B}$
}

Received: 3 June 2019/Accepted: 14 June 2019/Published online: 17 September 2019

(C) Springer Nature B.V. 2019

\section{The global challenge of rural-urban transformation}

During the last two decades the benefits, risks, negative externalities, and future social-ecological challenges of urban and (peri-) urban agriculture (UPA) have received increasing attention (Lydecker and Drechsel 2010; Safi and Buerkert 2011; Drechsel and Keraita 2014; Thebo et al. 2014). A main cause for this attention is the growing awareness of rapid ruralurban transformation processes that are changing matter flows, resource allocation, and ecosystem functioning as a consequence of strong shifts in the distribution of people along the rural-urban gradient (Cumming et al. 2014; Angel et al. 2005). It has been estimated that by 2050 the share of the global urban population may reach $68 \%$ compared with $55 \%$ today (United Nations 2017). Given continuing population growth, this phenomenon, in absolute numbers, entails

\footnotetext{
A. Buerkert $(\square)$

Organic Plant Production and Agroecosystems Research in the Tropics and Subtropics (OPATS), University of Kassel, Steinstrasse 19, 37213 Witzenhausen, Germany e-mail: buerkert@uni-kassel.de

E. Schlecht

Animal Husbandry in the Tropics and Subtropics, University of Kassel and Georg-August-Universität Goettingen, Steinstrasse 19, 37213 Witzenhausen, Germany

e-mail: schlecht@uni-kassel.de
}

the migration of hundreds of millions of people into urban areas. While the status quo of urbanization varies by continent with $>80 \%$ of the population already being urban in the Americas followed by $75 \%$ in Europe, $42 \%$ in Africa, and $50 \%$ in Asia, the rate of urbanization is much faster on the latter two continents (United Nations 2017). Rural-urban transformation is accompanied by rapid losses of prime agricultural land in urban areas which until 2050 are estimated to reach $2 \%$ of the agricultural area globally, with $60 \%$ of it occurring in Asia (Bren d'Amour et al. 2016). In this context provisioning, supporting, and regulating cultural ecosystem services, which characterise ecological and social systems in rural and urban contexts, are increasingly challenged (Pickett et al. 2014). This special issue highlights a range of recent or future problems related to UPA and possible approaches for their mitigation.

\section{Externalities of UPA}

The advantages of UPA production systems comprise the supply of fresh vegetables, fruits and dairy products to consumers (Diogo et al. 2010a, b; Fig. 1), and they may also foster the conservation of plant biodiversity and pollinator functions (Bernholt et al. 2009). Also reported are provision of jobs and income opportunities for (poor) producers and street vendors across value chains, recycling of water and 

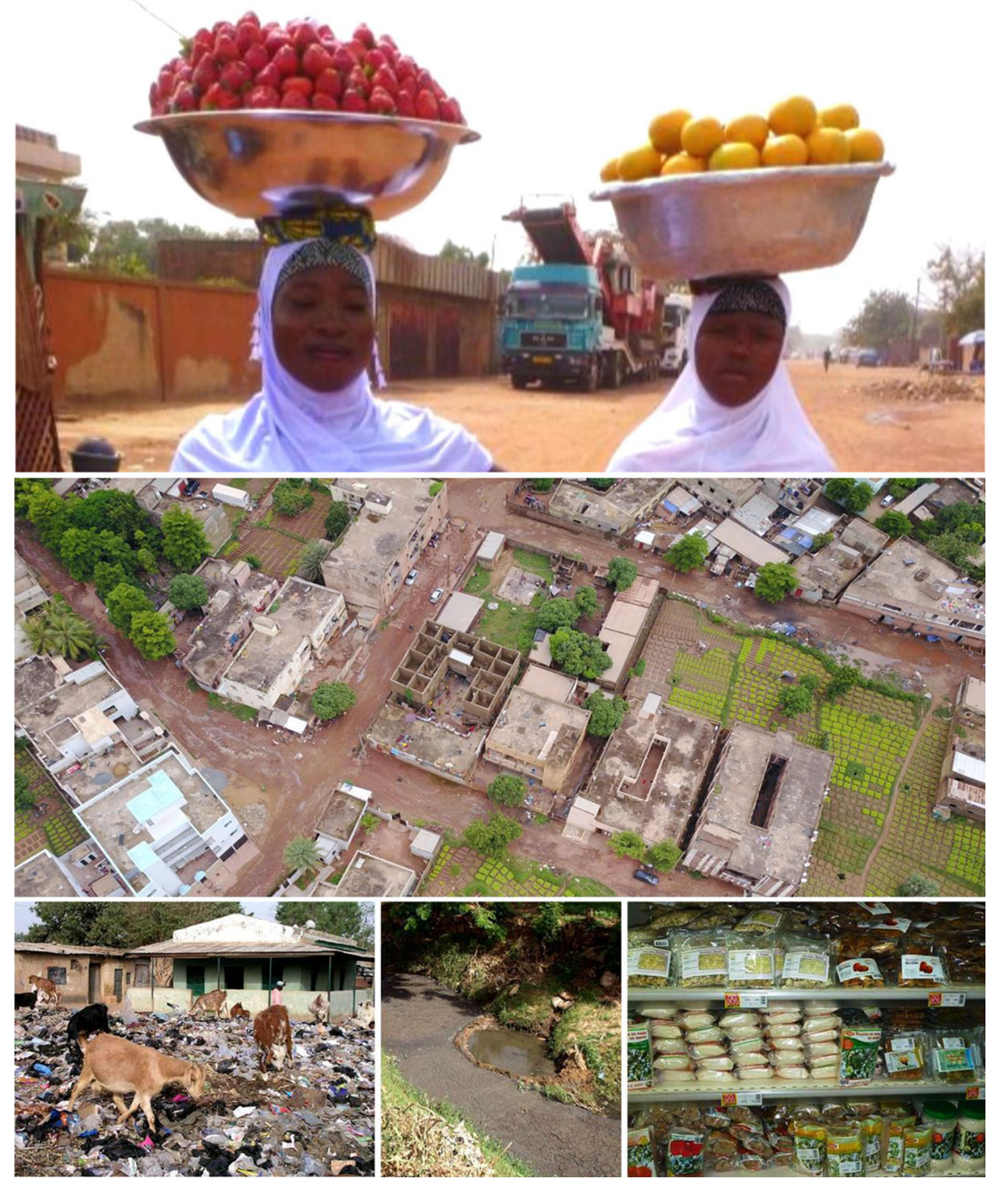

Fig. 1 In many low-income countries of the Global South, urban and peri-urban agriculture (UPA) strongly depends on the effective recycling of waste water and other urban resources such as idle land, abundance of capital, cheap labour, and reliable consumer markets. UPA thereby also addresses multiple demands of urban consumers for ecosystem services. Problems of recycling of nutrients become evident in large leaching and

organic waste, and coverage of free space with urban green (Graefe et al. 2019). Nevertheless, a major problem of UPA are lacking legal frameworks for this mode of production including tenure rights for the producers (Cabannes 2012). Most producers are illegally occupying land and can easily be pushed away when land developers need their plots. The same is true for livestock systems in cities as animals are volatilisation losses, high faecal bacterial loads and pesticide residues of agricultural produce. Curbing these negative externalities of UPA requires sensible regulations taking into account the needs of producers and consumers in a highly dynamic social-ecological environment driven by new quality criteria along value chains and global competition for goods and services

often regarded as a nuisance given related odor and manure production. An exception to this is India where cattle in cities have a very important cultural role and are thus tolerated even if legislators may have recently tried to confine them to colonies (Prasad et al. 2019). Also crop production along Indian railway tracks is strongly regulated and tenants have a land title linked 
to their obligation of keeping the tracks clear of building encroachment (Vazhacharickal et al. 2013).

Research and development efforts in UPA indicate that in contrast to widespread concern of consumers and administrators, heavy metal contamination of UPA produce from dust deposition or wastewater irrigation seem to be much less of a human toxicity problem than the contamination with faecal pathogens (Abdu et al. 2011; Akoachere et al. 2018; Dao et al. 2018), except for very specific cases in the tanning and dying industry of countries with lacking or poorly enforced legislation, such as Nigeria (Mashi and Alhassan 2007) or Pakistan (Rehman et al. 2008). Pathogen contamination of fresh (peri-)urban produce, however, is often not recognized as a serious problem by the local population as diarrhea and related early child death are common phenomena which have many causes. Uptake of heavy metals in UPA is generally low due to the comparatively high $\mathrm{pH}$ and organic carbon levels of UPA soils to which often large amounts of organic waste are applied, including sewage sludges, manure, and composts of varying origin and quality. While it is well known that plastics ingested by ruminants in grazing fields or on municipal dumpsites accumulate in their rumen and may cause animal death (Mushonga et al. 2015), it remains open to further research whether microplastic particles produced in this context are a health concern for animals or humans as they enter the food chain.

While UPA undoubtedly provides important pathways to recycle organic waste in urban areas, links between urban livestock keepers and vegetable producers are often weak or even lacking. This may be because of attractive alternative uses for manure, such as shown for the brick industry in Khartoum (Sudan; Abdalla et al. 2012; Babiker Abdalla et al. 2012), fuel material in Faisalabad (Pakistan; Erbach 2014) or because manure management and transport seem too cumbersome compared to the easy availability of mineral fertilizers.

Open nutrient cycles in UPA systems may become a concern as balance studies demonstrated that excessive surplus of nutrients can lead to large volatilization and leaching losses during manure storage or after field application (Predotova et al. 2010a, b; Diogo et al. 2010a, b). On the other side, detailed studies indicate that regular manure and compost applications are necessary to maintain organic carbon balances in year-round cropped and intensively irrigated UPA plots (Lompo et al. 2019).

\section{Food self-sufficiency and telecoupling}

Given their high population densities and related consumer demands, cities are major sinks for resources among which food, fiber, energy, labour, and water are the most important. In recent years numerous studies have been conducted to quantify the dependence of cities from their hinterland whereby for food so called "foodsheds" were defined. They describe the area from which food items come andin combination with the virtual water contained in imported food-allow to link local consumption patterns with regional and even global supply (telecoupling; Liu et al. 2013; Drechsel et al. 2007; Karg et al. 2016). Depending on the time-resolution of the data collected, these dependencies may have cropspecific, seasonal patterns and may thus gain substantial political relevance. They allow predicting the effects of price increases for imports as well as responses to taxation and transport blockage. At the regional and global level, such studies may contribute to making food aid, water use and resource planning more effective (Akoto-Danso et al. 2019a).

\section{The road ahead}

With a global population reaching 9.7 billion by 2050 (UN DESA 2017), continuing rural-urban transformation and increasing demands for instant availability of healthy, fresh and affordable food, agriculturalists once more are asked to enhance production and efficiency on shrinking land resources. Increasingly well-defined standards for modes of food production (e.g. organic food), labour rights, food quality and safety, carbon and water footprints, and use efficiency of nutrients and space will need to be implemented.

The ten papers compiled in this volume report about recent collaborative research in Africa and Asia conducted along these lines. They provide a comprehensive review of the available scholarly literature on the topic as well as data from well-defined case studies and insights into social-ecological production systems along urban value chains. The introductory review (Graefe et al. 2019) on recently published studies 
dealing with UPA in general and particularly in tropical countries highlights the widespread concerns about food safety-in particular of vegetables-produced in cities. It also points to the largely untapped potential of close crop-livestock integration in and around cities which could enhance nutrient use efficiency. In line with the general trend, the majority of contributions investigate urban and peri-urban vegetable cultivation. Four contributions from Burkina Faso and/or Ghana focus on nutrient balances in urban vegetable production, thereby also testing the effects of biochar as a soil amendment. At UPAtypical fertilizer application levels exceeding official recommendations four- to seven-fold, apparent nutrient use efficiency of potassium (K) and nitrogen (N) ranged from 54 to $85 \%$ and from 44 to $66 \%$, respectively (Lompo et al. 2019). The application of $20 \mathrm{t} \mathrm{ha}^{-1}$ of biochar improved marketable average yields of different UPA crops by $6 \%$, but yield increases were significant only on fertilized plots (Manka'abusi et al. 2019). On unfertilized plots, vegetable yields increased with wastewater irrigation, by a factor of 10-20 during the dry season and by a factor of 4 during the wet season. Fertigation with wastewater thus contributed to nutrient recovery within the city while yield-increasing biochar effects disappeared with irrigation (Akoto-Danso et al. 2019b). When irrigation exceeded crop demands, N leaching losses in the order of $200 \mathrm{~kg} \mathrm{~N} \mathrm{ha}^{-1}$ were measured. The high nutrient load of wastewater contributed to these losses, which could not be curbed by biochar application to the soil (Werner et al. 2019). The contribution investigating vegetable contamination with heavy metals in railway gardens of Mumbai, India, reports that the related health threat of consumers is moderate to considerable (Vazhacharickal et al. 2019). Three contributions of this issue focus on nutrient use efficiency in urban and peri-urban livestock holdings. An estimated 190,000 farm animals (tropical livestock units of $250 \mathrm{~kg}$ body weight) are currently kept in Ouagadougou, Burkina Faso. In nearly $70 \%$ of the studied cases, their homestead feeding was characterized by excess $\mathrm{N}$ supply. Through their (partly unused) manure an annual amount of up 1100 tons $\mathrm{N}$ is estimated to accumulate in the peri-urban space (Schlecht et al. 2019). Likewise, $\mathrm{N}$ use efficiency was found to be suboptimal in peri-urban crop-livestock systems of two Ethiopian cities. Suggested improvement measures across the studies include targeted exchange of crop residues and manure between crop and livestock activities within and between farms and precision feeding (Tadesse et al. 2019). At the national level, exemplified for India, nutrient fluxes in UPA livestock systems are related to feed production, transformation of nutrients from feed into animal products, and waste management. Enhancing nutrient recycling efficiency therefore requires strengthened crop-livestock links and increased awareness of stakeholders (Prasad et al. 2019). However, no city is self-sufficient in food production: Tamale in Ghana and Ouagadougou in Burkina Faso, for example, import $10 \%$ and $40 \%$ of the $\mathrm{N}$ contained in human food from outside the country. In Tamale, $50 \%$ of the food nutrient inflows leave the city again for other destinations, pointing to the cities' function as food trading hubs (Karg et al. 2019). Whether or not raising urban demands for meat in Asia and Africa (OECD/FAO 2016) can be met by local producers and thereby also generate new opportunities for rural livestock keepers to regularly sell their products and thus enhance the resilience of agropastoral dryland systems, will partly depend on local infrastructure and flexible food processing and distribution systems. The same is also true for staples and vegetables, of which UPA only covers part of the cities' demand (Karg et al. 2016). In any case (urban) consumers' demands for multiple ecosystem services will likely increase faster than their willingness to pay for what they long had for free. Across rural to urban production systems and value chains, this will require enhanced resource use efficiency, factor productivity and a strengthening of the systems' resilience against shocks to cope with the often location-specific effects of climate change and market developments.

Acknowledgements The paper was conceived in the context of the Research Unit FOR2432 Social-Ecological Systems in the Indian Rural-Urban Interface: Functions, Scales and Dynamics of Transition jointly funded by Deutsche Forschungsgemeinschaft (DFG; Grant Number: BU1308/14-1/ 2 and SCHL587/ 6-1/2) and the Department of Biotechnology (DBT), Government of India. Also contributed has collaborative research within the UrbanFood project funded by the Volkswagen Foundation (Hannover, Germany) under its Africa initiative "Resources, their Dynamics, and Sustainability: Capacity-Development in Comparative and Integrated Approaches" (Grant Number: I/82 189) and the UrbanFood $^{\text {Plus }}$ project jointly funded by the German Federal Ministry of Education and Research (BMBF) and the German Federal Ministry for Economic Cooperation and Development 
(BMZ) under the initiative "GlobE-Research for the Global Food Supply” (Grant Number: 031A242-A).

\section{References}

Abdalla I, Babiker Abdalla S, El Siddig K, Möller D, Buerkert A (2012) Effects of red brick production on land use, owner income, and greenhouse gas emissions in Khartoum, Sudan. J Agric Res Trop Subtrop 113(1):51-60

Abdu N, Agbenin J, Buerkert A (2011) Phytoavailability, human risk assessment and transfer characteristics of cadmium and zinc contamination from urban gardens in Kano, Nigeria. J Sci Food Agric 91:2722-2730

Akoachere JFTK, Tatsinkou BF, Nkengfack JM (2018) Bacterial and parasitic contaminants of salad vegetables sold in markets in Fako Division, Cameroon and evaluation of hygiene and handling practices of vendors. BMC Res Notes 11:100

Akoto-Danso EK, Karg H, Nyarko G, Drechsel P, Buerkert A (2019a) Virtual water flow in food trade systems of two West African cities. Agric Water Manag 213:760-772

Akoto-Danso EK, Manka'abusi D, Steiner C, Werner S, Haering V, Nyarko G, Marschner B, Drechsel P, Buerkert A (2019b) Agronomic effects of biochar and wastewater irrigation in urban crop production of Tamale, northern Ghana. Nutr Cycl Agroecosyst 115(2):231-247

Angel S, Sheppard SC, Civo DL (2005) The dynamics of global urban expansion. World Bank, Washington

Babiker Abdalla S, Gebauer J, Predotova M, Buerkert A (2012) Horizontal nutrient flows and balances in irrigated urban gardens of Khartoum, Sudan. Nutr Cycl Agroecosyst 92(2):119-132

Bernholt H, Kehlenbeck K, Gebauer J, Buerkert A (2009) Plant species richness and diversity in urban and peri-urban gardens of Niamey, Niger. Agrofor Syst 77(3):159-179

Bren d'Amour C, Reitsma F, Baiocchi G, Barthel S, Güneralp B, Erb K-H, Haberl H, Creutziga F, Seto KC (2016) Future urban land expansion and implications for global croplands. Proc Natl Acad Sci 114(34):8939-8944

Cabannes Y (2012) Pro-poor legal and institutional frameworks for urban and peri-urban agriculture. FAO Legislative Study 108. Food and Agriculture Organization of the United Nations, Rome, Italy

Cumming GS, Buerkert A, Hoffmann EM, Schlecht E, von Cramon-Taubadel S, Tscharntke T (2014) Implications of agricultural transitions and urbanization for ecosystem services. Nature 515:50-57

Dao J, Stenchly K, Traore O, Amoah P, Buerkert A (2018) Effects of water quality and post-harvest handling on microbiological contamination of lettuce at urban and periurban locations of Ouagadougou, Burkina Faso. Foods 7:206

Diogo RVA, Buerkert A, Schlecht E (2010a) Horizontal nutrient fluxes and food safety in urban and peri-urban vegetable and millet cultivation of Niamey, Niger. Nutr Cycl Agroecosyst 87(1):81-102

Diogo RVA, Buerkert A, Schlecht E (2010b) Resource use efficiency in urban and peri-urban livestock enterprises of Niamey, Niger. Animal 4(10):1725-1738
Drechsel P, Keraita B (2014) Irrigated urban vegetable production in Ghana: characteristics, benefits and risk mitigation, 2nd edn. International Water Management Institute (IWMI), Colombo, Sri Lanka. https://doi.org/https://doi. org/10.5337/2014.219

Drechsel P, Graefe S, Fink M (2007) Rural-urban food, nutrient and virtual water flows in selected West African cities. Report 115. International Water Management Institute (IWMI), Colombo, Sri Lanka. https://doi.org/10.3910/ 2009.115

Erbach J (2014) The decency of women's working conditions in peri-urban dairy buffalo production systems in the District Faisalabad, Punjab, Pakistan. ICDD Working-Papers, paper No. 10. Kassel University Press, Kassel, Germany. https://d-nb.info/1057982512/34. Accessed 1 June 2019

Graefe S, Buerkert A, Schlecht E (2019) Trends and gaps in scholarly literature on urban and peri-urban agriculture. Nutr Cycl Agroecosyst 115(2):143-158

Karg H, Drechsel P, Akoto-Danso EK, Glaser R, Nyarko G, Buerkert A (2016) Foodsheds and city region food systems in two West-African cities. Sustainability 8(12):1175

Karg H, Akoto-Danso EK, Drechsel P, Abubakari A-H, Buerkert A (2019) Food- and feed-based nutrient flows in two West African cities. Nutr Cycl Agroecosyst 115(2):173-188

Liu J, Hull V, Batistella M, DeFries R, Dietz T, Fu F, Hertel TW, Izaurralde RC, Lambin EF, Li S, Martinelli LA, McConnell WJ, Moran EF, Naylor R, Ouyang Z, Polenske KR, Reenberg A, de Miranda Rocha G, Simmons CS, Verburg PH, Vitousek PM, Zhang F, Zhu C (2013) Framing sustainability in a telecoupled world. Ecol Soc 18(2):26

Lompo DJ-P, Compaoré E, Sedogo MP, Melapie M, Bielders CL, Schlecht E, Buerkert A (2019) Horizontal flows of nitrogen, potassium, and carbon in urban vegetables gardens of Bobo Dioulasso, Burkina Faso. Nutr Cycl Agroecosyst 115(2):189-199

Lydecker M, Drechsel P (2010) Urban agriculture and sanitation services in Accra, Ghana: the overlooked contribution. Int J Agric Sustain 8:94-103

Manka'abusi D, Steiner C, Akoto-Danso EK, Lompo DJ-P, Haering V, Werner S, Marschner B, Buerkert A (2019) Biochar application and wastewater irrigation in urban vegetable production of Ouagadougou, Burkina Faso. Nutr Cycl Agroecosyst 115(2):263-279

Mashi SA, Alhassan MM (2007) Effects of wastewater discharge on heavy metals pollution in Fadama soils in Kano city, Nigeria. Biomed Environ Sci 20:70-77

Mushonga B, Habarugira G, Musabyemungu A, Udahemuka JC, Jaja FI, Pepe D (2015) Investigations of foreign bodies in the fore-stomach of cattle at Ngoma slaughterhouse, Rwanda. J S Afr Vet Assoc 86(1):1233

OECD/FAO (2016) OECD-FAO agricultural outlook. OECD Agriculture Statistics, Paris. https://dx.doi.org/10.1787/ 888933381573

Pickett STA, McGrath B, Cadenasso ML, Felson AJ (2014) Ecological resilience and resilient cities. Build Res Inform 42(2):143-157

Prasad CS, Anandan S, Gowda NKS, Schlecht E, Buerkert A (2019) Managing nutrient flows in Indian urban and periurban livestock systems. Nutr Cycl Agroecosyst 115(2):159-172 
Predotova M, Gebauer J, Schlecht E, Buerkert A (2010a) Emissions of ammonia, nitrous oxide and carbon dioxide from urban gardens in Niamey, Niger. Field Crops Res 115:1-8

Predotova M, Schlecht E, Buerkert A (2010b) Nitrogen and carbon losses from dung storage in urban gardens of Niamey, Niger. Nutr Cycl Agroecosyst 87(1):103-114

Rehman W, Zeb A, Noor N, Nawaz M (2008) Heavy metal pollution assessment in various industries of Pakistan. Environ Geol 55(2):353-358

Safi Z, Buerkert A (2011) Heavy metal and microbial loads in sewage irrigated vegetables of Kabul, Afghanistan. J Agric Res Trop Subtrop 112(1):29-36

Schlecht E, Plagemann J, Mpouam SE, Sanon HO, Sangaré M, Roessler R (2019) Input and output of nutrients and energy in urban and peri-urban livestock holdings of Ouagadougou, Burkina Faso. Nutr Cycl Agroecosyst 115(2):201-230

Tadesse ST, Oenema O, van Beek C, Ocho FL (2019) Nitrogen allocation and recycling in peri-urban mixed crop-livestock farms in Ethiopia. Nutr Cycl Agroecosyst 115(2):281-294

Thebo AL, Drechsel P, Lambin EF (2014) Global assessment of urban and peri-urban agriculture: irrigated and rainfed croplands. Environ Res Lett 9:114002
UN DESA (2017) World population prospects 2017. United Nations, New York, NY, USA. https://population.un.org/ wpp/. Accessed 1 June 2019

United Nations, Department of Economic and Social Affairs, Population Division (2017) World population prospects: the 2017 revision, key findings and advance tables. ESA/P/ WP/248

Vazhacharickal PJ, Predotova M, Chandrasekharam D, Bhowmik S, Buerkert A (2013) Urban and peri-urban agricultural production along railway tracks: a case study from the Mumbai Metropolitan Region. J Agric Rural Trop Subtrop 114(2):145-157

Vazhacharickal PJ, Gurav T, Chandrasekharam D (2019) Heavy metal signatures in urban and peri-urban agricultural soils across the Mumbai Metropolitan Region, India. Nutr Cycl Agroecosyst 115(2):295-312

Werner S, Akoto-Danso EK, Manka'abusi D, Steiner C, Haering V, Nyarko G, Buerkert A, Marschner B (2019) Nutrient balances with wastewater irrigation and biochar application in urban agriculture of Northern Ghana. Nutr Cycl Agroecosyst 115(2):249-262

Publisher's Note Springer Nature remains neutral with regard to jurisdictional claims in published maps and institutional affiliations. 